\title{
The Archives of the Council for Religious Affairs
}

\author{
JOHN ANDERSON
}

Since 1989 it has been possible for western scholars to work in at least a part of the archive of the Council for Religious Affairs (CRA) attached to the USSR Council of Ministers. ${ }^{1}$ This research note is based upon my own experiences in the archive during July 1991, although its conclusions are limited by the relatively short period of time at my disposal on that visit.

The archive is to be found in the Tsentral'ny Gosudarstvenny Arkhiv Oktyabr'skoi Revolyutsii (Central State Archive of the October Revolution, TsGAOR) located in Moscow's Main Archival Administration on Bol'shaya Pirogovskaya ulitsa. Access to the archive requires, or at least did before last August's coup, a letter from a recognised Soviet institution - in my case the Institute of USSR History attached to the Academy of Sciences. Once one is past the door the archivists supply one with opisi (indexes) relating to the archive fond one wishes to work in. I was given four indexes relating to the work of the Council for the Affairs of the Russian Orthodox Church (CAROC) (1943-65) and the Council for the Affairs of Religious Cults (CARC) (1944-65). ${ }^{2}$

Two limitations of the material were immediately obvious: firstly, the apparent 25-year rule that limited access, in my case, to the period ending in December 1965 (a rule which is presumably updated each year); secondly, the fact that this was only a part of the archive, and that from the available opisi one could deduce the existence of other material still being kept from researchers without special contacts (this may have changed since the coup).

From the four lists I was allowed to choose a certain number of files to work with each day. The material contained in the open section of the archive included: documents relating to the setting up and roles of the councils; instructions and rulings issued by them; correspondence with other bodies; statistical tables relating to registered places of worship, priests, monastic institutions etc.; minutes of the regular sessions of the councils (though those were absent for some years); reports from regional commissioners; summaries of conversations between council employees and church leaders; reports written by religious leaders returning from foreign visits. What is lacking is detailed material on the councils' dealings with the Central Committee apparatus and the central political leadership in general.

In this report I cannot provide a detailed analysis of the material in the archive, but will simply pick out a few points of interest mainly relating to the Khrushchev period and to my own interests in religious policy making.

\section{Towards a New Campaign, 1958-1960}

With regard to the start of the Khrushchev campaign, the archive material would 
confirm the view that the new attack was launched in the autumn of 1958. Although the open section of the archive contains no documents from the Central Committee apparat launching a specific campaign, various clues can be found here. That a new campaign was coming was clearly the view of some of the Russian Orthodox hierarchs as expressed in their conversations with CAROC officials. In a talk with CAROC chairman G. Karpov and deputy chairman P. Chernyak in February 1959 Metropolitan Nikolai (Yarushevich) of Krutitsy and Kolomna raised the question of the new attack on the church, which he believed to have begun in the autumn of 1958. In particular, the hierarch raised the question of various decrees issued by the Council of Ministers restricting the activities of the monasteries. ${ }^{3}$ Two months later Nikolai raised this issue again and, in a clear attempt at bargaining, pointed to the harm this was doing to the Soviet image abroad. ${ }^{4}$

This perception of a systematic new attack was strengthened during the course of 1959 , and the archives contain numerous letters from individual parishes and dioceses expressing concern. In September of that year Archbishop Innokenti of Rostov-onDon wrote to Patriarch Aleksi expressing concern at the growing demands being made upon the church. In particular he noted the new demands that dioceses should provide state authorities with lists of churches and the names of members of the dvadsatki, that priests should not carry out prayers in private homes or allow those under 18 into churches, and that written permission from both parents was necessary before baptisms could be carried out. ${ }^{5}$

Although the records of talks between church leaders and CAROC chairman Karpov suggest that he simply refuted their talk of a new campaign there is some evidence to support the view that he was less than enthusiastic. In March 1959, for example, he wrote to RSFSR prime minister I. S. Polyansky complaining about the growing incidence of abuse of believers' rights in many parts of the Russian republic, notably in the Primorsky krai and the Rostov oblast'. This, he suggested, contradicted the Central Committee resolutions of 10 November 1954 and 4 October 1958 , which forbade interference in the internal affairs of the church. ${ }^{6}$

This reference to two Central Committee resolutions is worth noting, for the first in November 1954 had marked the ending of a brief anti-religious campaign during that year. The text of the latter has, to the best of my knowledge, not been published, but it is interesting that Karpov interprets in a 'liberal' fashion a decree issued by the Central Committee in the very month that the new anti-religious assault appears to have begun. Although we can only speculate, one might assume that this was the decree that announced the new policy turn to party organisations, but that Karpov was quoting the section, standard to all official statements on the religious communities. $^{7}$

on 'the impermissibility of administrative actions' against the religious communities. 7

The perception that Karpov was less than enthusiastic was apparently the view of the party authorities, for in early 1960 he was replaced as CAROC chairman by V. A. Kuroyedov, a man who had few qualms about attacking the church. The latter wasted no time in making his presence felt. In a talk with Patriarch Aleksi in June 1960 he suggested that there were many shortcomings in the work of the Moscow Patriarchate's Foreign Affairs Department (under Metropolitan Nikolai) and 'recommended' that its chairman be replaced. ${ }^{8}$ One month later Nikolai retired on 'health grounds', and some time later he died in circumstances that led many to believe he had been murdered. ${ }^{9}$ With his death more overt resistance to the new campaign from within the Moscow Patriarchate was stifled to a considerable degree. 


\section{Statistics on Closure of Places of Worship}

Various files in the archive give detailed statistics on the number of registered places of worship in the USSR, and enable us to check up on the impact of Khrushchev's campaign on various religious groups. Among other things the materials confirm the view held by many that the number of Orthodox churches active in the mid-1950s was far below the oft-quoted 20,000 or more. This subject is dealt with elsewhere by Nathaniel Davies (see note 1), so I shall simply note here that according to the archives there were some 13,477 on 1 January $1957^{10}$ and that by the mid-1960s there were probably no more than 7,500 functioning Orthodox churches. Protocols of CAROC meetings provide a sorry litany of decisions to approve the actions of local authorities who were depriving communities of registration. For example, at their meeting in January 1964 some 14 lost their registration, in February 18, in March 91, and so on. ${ }^{11}$

What is also noteworthy from the various statistical tables is the much greater impact of the campaign on the Orthodox Church than on other religious groups. Perhaps as many as $\mathbf{4 5}$ per cent of Orthodox parishes were deprived of registration during these years, whereas less than 20 per cent of the religious communities falling under the jurisdiction of the Council for the Affairs of Religious Cults were closed. From various files one can compile a table for the impact of the new assault on the non-Orthodox (Table 1).

Table 1.

Numbers of non-Orthodox places of worship in 1958 and 1964

\begin{tabular}{lrr}
\hline Roman Catholic & 1,244 & 1,046 \\
Lutheran & 451 & 452 \\
Reformed & 96 & 86 \\
Armenian & 48 & 32 \\
Muslim & 402 & 312 \\
Jewish & 135 & 92 \\
Buddhist & 2 & 2 \\
Old Believer & 397 & 336 \\
AUCECB (Baptist) & 2,119 & 1,663 \\
Seventh Day Adventist & 186 & 140 \\
Molokans & 17 & 15 \\
Others & 11 & 11 \\
Total & 5,108 & 4,187 \\
\hline
\end{tabular}

Source: TsGAOR, op. 4, ed. khr. 258, p.3; ed. khr. 430, p.1

I intend to explore the implications of these statistics in depth elsewhere, but explanations for the differential might be found in the specific targeting of the Orthodox; in varying degrees of commitment to the campaign by implementing bodies (in particular the two councils); and in the ability of different religious groups to thwart official policies. It is perhaps worth noting from the archive material that Kuroyedov and his council exhibited a considerable degree of enthusiasm for the assault on the church, whereas in the CARC archives are to be found odd hints of distaste for the more excessive measures.

Both councils sought to maintain detailed information on non-registered communities and their make-up. Reporting to CARC in 1964 the commissioner for Krasnoyarsk region, I. S. Savchenko, noted the existence of 98 sectarian communities, most of them unregistered. These included six groups of initsiativniki, 22 groups 
of Jehovah's Witnesses, and 23 Pentecostal groups - including that led by the Vashchenkos. These latter groups comprised 491 believers, of whom 79 per cent were women and 41 per cent were under 40 . He also noted that there were 370 religious activists in exile in the region and that 467 people had refused to vote on religious grounds. ${ }^{12}$

Such detailed information on religious groups was encouraged by the councils long before the new campaign, and in the early 1950s they had issued a form to commissioners that required reports on a whole host of topics. Thus the commissioner for the Poltava oblast', reporting on the synagogue in Dubna, noted that it was located on Dostoyevsky St, that it was registered in December 1946 but was active before that date, that it had two rooms and 42 square metres, that the building was constructed in 1898 , and that it was 60 kilometres from the next Jewish prayer house. Its rabbi was Moses Mashov (b. 1884), who had no theological training and had completed only three classes of secular education. Some 15 people attended regular services, although this number doubled for feastdays. ${ }^{13}$ The archive as a whole is full of these details on individual communities, which are often fascinating, if not always kind to their subjects.

\section{Rethinking Religious Policy (1965)}

The archives contain extensive material on the rethinking of Soviet religious policy after Khrushchev's fall and suggest a considerable degree of debate within the elite. Of particular concern was the schism within the Baptist community. A special meeting of the Presidium of the Supreme Soviet was called to discuss the issue - among those present were Soviet president Mikoyan and KGB chairman Semichastny - and a special commission was set up to seek a solution. On 27 January 1965 the Presidium of the Supreme Soviet issued a decree on the subject of abuses of believers' rights and in June CARC requested its commissioners to provide information on how they were implementing this decree. In particular it wanted to know what sorts of violations were still being committed (by of ficials and believers), how many court judgments had been overturned, and what matters remained unresolved. ${ }^{14}$

In March 1965 CARC hosted a further meeting on the subject of administrative abuses at which much attention was paid to the Baptist issue. This meeting was attended by of ficials of the two councils (including CARC chairman Puzin and CAROC's Furov), representatives of the atheist establishment (Klibanov, Filimonov, Mitrokhin, Okulov, Kurochkin, Belov), lawyers (such as Rozenbaum) and officials of the party apparatus and KGB. Puzin's opening speech suggested that to a considerable extent the schism had its origins in breaches of socialist legality by state authorities. He rejected the view that an atheist society could be created by the closure of churches and, turning to other religious groups, noted the absurdity of situations such as that prevailing in Checheno-Ingushetia, where there were now no mosques. Various speakers noted the tendency of persecution to push believers into illegality and expressed doubt as to the anti-Soviet nature of sectarian activities. Yuri Rozenbaum, who was to become prominent once more in the late 1980s, noted that: 'Year after year we have created the impression amongst broad sections of the workers... that believing people are harmful people. When I have been in an oblispolkom or in party organisations I have noted that workers there often speak of such people in the third person - "they".' And he went on to criticise the predominance of unpublished legislation which believers were expected to conform to but had no knowledge of. Yet other speakers criticised CAROC for its militant 
approach to the closure of churches. ${ }^{15}$

Over the next few months CARC held further discussions on the subject of the Baptists, and simultaneously began to make it easier for them to register. Protocols for subsequent months provide evidence of a gradual reversal of previous policy, with more than 50 congregations registered by the end of the year. ${ }^{16}$

\section{Conclusion}

Even in the absence of key materials, the CRA archive is a mine of information for the student of Soviet religious policy. At the micro level it is possible to add the documents contained here to Soviet press reports and samizdat material to produce detailed studies of individual regions or religious groups - though some receive rather limited coverage. From the letters written to the CRA by church leaders and others one gets a feel of how, if at all, they sought to resist or blunt the edge of hostile policies. The reports written by religious activists who had been on the pilgrimage to Mecca provide insight on what they thought the state wanted to hear, as well as suggesting the different ways in which individuals interpreted their foreign responsibilities. The material also confirms suspicions that the religious sphere was not completely free of the bureaucratic politics that became more prominent in the Khrushchev years.

For the scholar these materials mark the first stage in the development of a more thorough study of Soviet religious policy. It is to be hoped that all the relevant archives will be preserved and that those still hidden - whether CRA, KGB or CPSU - will soon become available to those attempting to document the tragedy of church-state relations during the Soviet period.

\section{Notes and References}

1 See the use made of the archive material in Nathaniel Davis, 'The number of Orthodox churches before and after the Khrushchev anti-religious drive', Slavic Review, vol. 50, no. 3 (1991), pp. 612-20.

2 On the CRA see W. Sawatsky, 'Religious administration and modernisation', in D. Dunn (ed.), Religion and Modernization in the Soviet Union (Westview, Boulder, CO, 1977), pp. 60-104; John Anderson, 'The Council for Religious Affairs and the shaping of Soviet religious policy', Soviet Studies, vol. 43, no. 1 (1991), pp. 689-710. The latter needs some slight revisions in the light of material found in the CRA archive.

3 TsGAOR, f6991s, op. 2, 'Zapisi besed', ed. khr. 255, p. 4.

4 ibid, p. 40.

5 TsGAOR, op. cit., ed. khr. 176, 'Pis'ma patriarkha Aleksiya v sovete po delam RPTs' (1955), pp. 49-50; in another document CRA official V. Vasil'yev speaks of near panic in the Patriarchate which is in receipt of a flood of letters from all over the country detailing new problems (ed. khr. 226).

6 TsGAOR, op. cit., ed. khr. 254, p. 29.

7 I shall examine the origins of the Khrushchev campaign more fully in a chapter in a forthcoming book on the shaping of Soviet religious policy.

8 TsGAOR, op. cit., ed. khr. 284, pp. 29-30.

9 TsGAOR, op. cit., ed. khr. 529 includes an anonymous letter forwarded to the KGB by Kuroyedov which alleges the involvement of other leading hierarchs in the murder of Nikolai. For the circumstances surrounding Nikolai's death see W. Fletcher, Nikolai: Portrait of a Dilemma (New York, 1968).

10 TsGAOR, op. cit., ed. khr. 180, p. 22. The figure I quote here differs slightly from that 
provided by Davis, op. cit., p. 613, who has a figure of 13,430. Mine comes from a different file.

1 TsGAOR, op. cit., ed. khr. 526 contains the protocols of CAROC sessions for 1964, although it is notable that by the second half of 1964 there are occasional cases where the council refused to recognise deregistration acts, often in situations where the believers complained particularly vigorously.

12 TsGAOR, op. cit., ed. khr. 146, pp. 53-61.

13 TsGAOR, op. cit., ed. khr. 27, p. 61.

14 TsGAOR, op. cit., ed. khr. 170, p. 14.

15 TsGAOR, op. cit. ed. khr. 168, pp. 70-203. Rozenbaum's position here, as in the late 1980s, was ambiguous. In June 1964 CARC had protested to the Central Committee and the Procuracy about one of Rozenbaum's articles in Nauka i religiya which had interpreted the law particularly rigorously regarding the baptism of children and was, in their view, likely to lead to administrative abuses against the clergy (ed. khr. 147, pp. 8-9). But in 1965 Rozenbaum had become the perfect 'liberal'!

16 TsGAOR, op. cit., ed. khr. 169. 